Herringham, Lancet, 1899, i, 834. Hill, Alex, Brain, 1896. Hill, L., The Cerebral Circulation, 1896, Lancet, January 29th, 1898. Hodge, Amer. Journ. of Poychol. v, i, Journ. of Morph. vii, 1892. Howell, Journ. of ExperiWïrbur. zu Wurzburg, March gth, 1895, p. 36. Lambert, Comp. Kend. de la soc. de Biol, r893. Lépine, Rev. de Med., r894; Comp. Rend. de la Soc. de Biol., 1895 . Lugaro, BRITISH MEDICAL JouRNAL, 1899, 1, 93. Ludwig, W., Dissert., Bonn, 1876. Mann, Journ. Anat. and Phy. 1894. Manacếne, Sleep, its Physiology, etc., 1897. Rabl-Ruckhard, Neurolog Centralbl., r89o. Ramon y Cajal, Proc. Roy. Soc., lv, p. 462 , 1894 ; Nouvelles laees du Systeme Nerveux, 1895, Arch. f. Anat. u. Physiol., r895. Vas., Arch. f. exp. Path. u. Pharm., Deut, med. Woch., N0. 5o, I8gr.

\section{CASE OF MULTiple ADENOMATA OF THE SKIN.}

Bx ROBERT Y. AITKEN, M.D.GLasG., Senior House-Surgeon, Blackburn Infirmary.

THE patient, G. E., aged 43 is one of a family of three. She has had two children; one died aged two years, and the other is now 24 years of age, and in neither, or in any other relative, has there been any manifestation of the mother's disease. The patient came to the Blackburn and East Lancashire Infirmary in October, 1897, and asked to have some lumps removed from her head as they were rather unsightly and prevented her wearing a hat comfortably. She stated that thirteen years previously she noticed some small lumps growing on her forehead, scalp, and ears. They gave no pain, but had gone on increasing in size and number

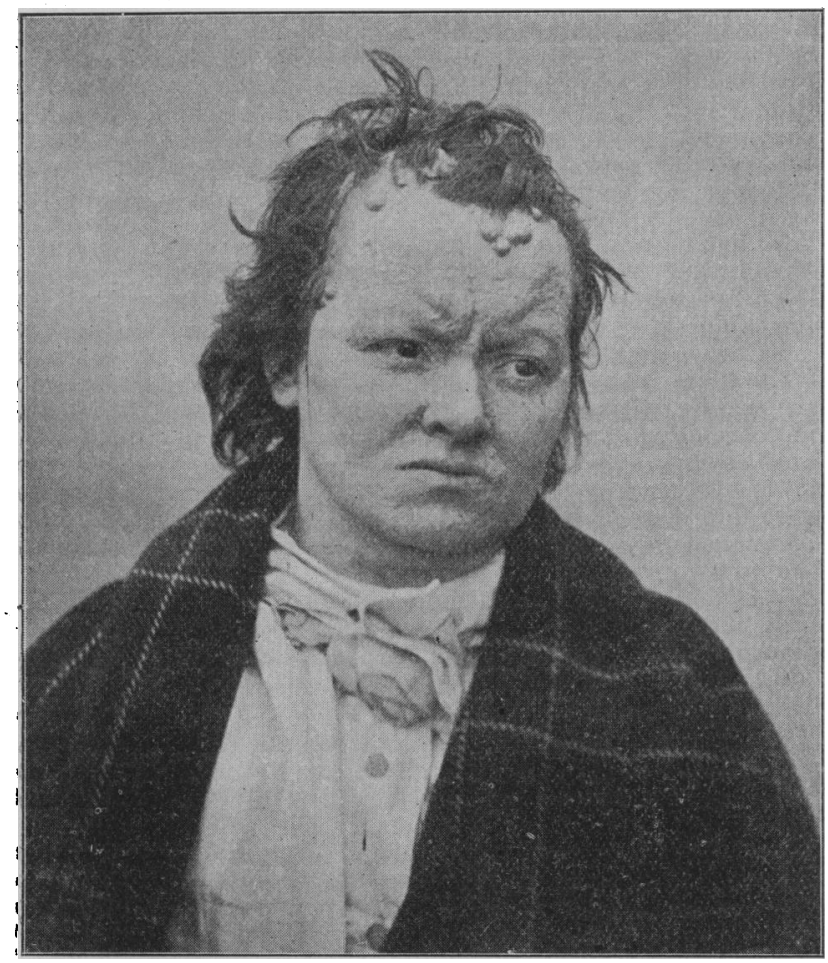

Multiple Adenomata of Skin.

till there were quite thirty scattered over the forehead, scalp, and ears. There were a few very small ones scattered over the trunk. The largest was 2 inches long and 1 inch wide, and projected from the scalp about I inch. It, like many of the others, was slightly pedunculated. The skin over it was hairless and apparently atrophied, being smooth and shining, and having a few enlarged blood vessels coursing over its surface. The other tumours were more rounded than this, which seemed to have been formed by thefusion of two masses originally separate. The tumours varied in size from mere papules to large cherries, and although most were slightly pedunculated, were quite immovable in the scalp. They were, however, not attached to the underlying bone in any way. One on the right temple was shaped like a mushroom with a very short stem, the shape being no doubt produced by the pressure of the head on the pillow during sleep. The tumours felt solid, and were quite painless.

A day or two after admission to the infirmary about a dozen of the more prominent tumours were excised by Mr. Hunt. They had to be dissected off the pericranium. There was free bleeding for a few minutes but it stopped when the sutures were tightened.

On section the tumours looked like fibrous tissue to the naked eye, but under the microscope the appearances were, I think, rather unusual. The section shows masses of epithelioid cells arranged very regularly in a fibrous tissue stroma, the whole surrounded by a thin connective tissue capsule. These masses vary in shape but are for the most part round or oval; here and there they are cylindrical, or more irregular in shape, this, no doubt, depending on the direction of the section. The cells at the periphery of these masses are arranged in columnar fashion. The cells are for the most part round or oval, and their 'large nuclei stain readily.

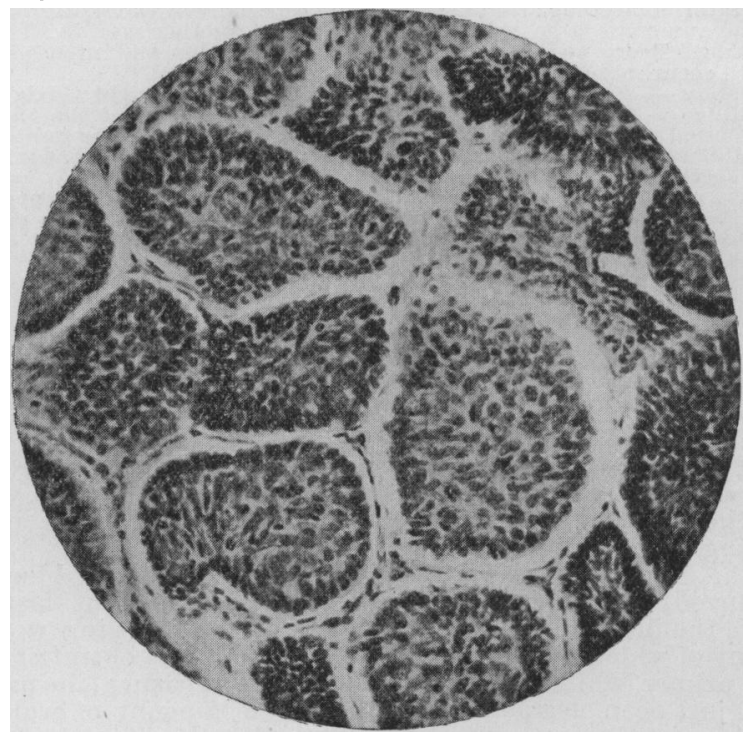

Section of Tumour.

Clinically the tumours "are certainly not malignant. There has never been any tendency to ulceration in any of them. A case, apparently of a similar nature, is recorded by Dr. James W. Barrett and Dr. Percy Webster, of Melbourne, in the British Medical Jodrnal of February 6th, 1892. They call their case one of "Multiple Sudoriparous Adenomata of the Scalp." Mr. Jonathan Hutchinson, sen., in his Archives, vol. vi, No. 2I, Plate cxIx, illustrates this case, but limits the name to "tumours of the scalp." The photograph of the patient was taken six months after she was first seen, and the tumours now noticed are distinctly but very little larger than they were then.

I am indebted to Mr. Hunt for permission to publish the case.

Italian Laryngological Socierty.-The Italian Society of Laryngology, Otology, and Rhinology will hold its fourth general meeting in Rome in October of the present year, under the presidency of Professor Giuseppe Gradenigo of Turin. The subjects proposed for discussion are: (I) The paths and modes of diffusion of tympano-mastoid infection (to be introduced by Professor Camillo Poli of Genoa; (2) the physiopathology of the olfactory nerves (to be introduced by Prufessor Vittorio Grazzi of Pisa); and (3) parasyphilitic or postsyphilitic lesions of the larynx. The following question will also be proposed for discussion : The Title of Specialist in Oto-rhino-laryngology. 